Оригинални научни рад

Rodoljub Etinski, Ph.D., Full Professor

University of Novi Sad

Faculty of Law Novi Sad

\title{
INDIRECT DISCRIMINATION IN THE CASE-LAW OF THE EUROPEAN COURT OF HUMAN RIGHTS
}

\begin{abstract}
The European Court of Human Rights has extended a scope of applicability of Article 14 of the European Convention on Human Rights to indirect discrimination in recent years. The change has happened in a context of turning attention in the Council of Europe and the European Union to the protection of particularly vulnerable groups. The Court has defined its concept of indirect discrimination as a general policy or measure which is apparently neutral but has disproportionately prejudicial effects on members of particularly vulnerable groups. The Court's finding on indirect discrimination in cases where discrimination was based on a language criterion and affecting exclusively Roma children requires an investigation of the definition.
\end{abstract}

Key words: Indirect discrimination - human rights.

\section{Introduction}

Only in recent years the European Court of Human Rights (hereinafter: the ECtHR or the Court) has begun to apply a concept of indirect discrimination. The International Centre for the Legal Protection of Human Rights, an international NGO based in London, published rightly in 2005 that: "...there are no clear examples from ECHR jurisprudence of a successful allegation of indirect discrimination. At any rate, the distinction between direct and indirect discrimination is not something that the ECtHR focuses on in its jurisprudence. “1 However, while the publication was in print, the change has happened. The change

${ }^{1}$ INTERIGHTS, Non-Discrimination in International Law, A Handbook for Practitioner, ed. Kevin Kitching, London, 2005, p. 83. 
was announced in Hoogendijk in 2005 . $^{2}$ The Zarb Adami case has certain importance in development of the Court's case-law towards indirect discrimination. ${ }^{3}$ In D.H. and Others the ECtHR observed: "the evidence submitted by the applicants can be regarded as sufficiently reliable and significant to give rise to a strong presumption of indirect discrimination." ${ }^{4}$ In Sampanis et autres ${ }^{5}$ and Horvath and $\mathrm{Kiss}^{6}$ and $\mathrm{Opuz}^{7}$ the ECtHR based its judgments on an application of prohibition of indirect discrimination. In Oršuš and Others the Court found "that the applicants must have sustained non-pecuniary damage - in particular as a result of the frustration caused by the indirect discrimination of which they were victims. ${ }^{\text {" }}$ Now, there is no doubt that the ECtHR has confirmed that Article $14^{9}$ of the 1950 Convention for the Protection of Human Rights and Fundamental Freedoms (hereinafter: the ECHR) covers indirect discrimination.

The text will present the shortest reviews of the mentioned cases. It will try to discuss a cause for the extension of Article 14 of the ECHR to indirect discrimination and the concept of indirect discrimination as developed by the Court. The text will finish by critical observations and concluding remarks.

\section{Review of the Case-Law}

\subsection{The Hoogendijk Case}

To adapt the social insurance scheme relating to incapacity for work to available budget, the Netherlands reduced a range of persons eligible to benefit to those who have lost income after the materialisation of the risk. By amendments to the General Labour Disablement Benefits Act in 1979 and 1989, the Netherlands legislature made receipt of a benefit for incapacity for work subject to the requirement of having received a certain income from or in connection with work in the year preceding the commencement of incapacity. A criterion of distinction of persons who had and who did not have an entitlement to a benefit

${ }^{2}$ Hoogendijk v. The Netherlands (App. no. 58641/00) Decision as to the admissibility of 6 January 2005.

${ }^{3}$ Zarb Adami v. Malta (App. no. 17209/02) Judgment of 20 June 2006.

${ }^{4}$ D.H. and Others v. the Czech Republic (App. no. 57325/00) Judgment (GC) of 13 November 2007, para 195.

${ }^{5}$ Sampanis et autres c. Grèce (Req. No. 32526/05) Arrêt 5 juin 2008 .

${ }^{6}$ Horváth and Kiss v. Hungary (App. no. 11146/11) Judgment of 29 January 2013.

${ }_{8}^{7}$ Opuz v. Turkey (App. no. 33401/02) Judgment of 9 June 2009.

8 Ořšš and Others v. Croatia (App. no. 15766/03), Judgment (GC) of 16 March 2010, para 191.

${ }^{9}$ Article 14 of the ECHR reads: "The enjoyment of the rights and freedoms set forth in this Convention shall be secured without discrimination on any ground such as sex, race, colour, language, religion, political or other opinion, national or social origin, association with a national minority, property, birth or other status." 
for incapacity for work was - receiving an income from or in connection to work. The criterion was not based on sex. However, since a lot of married women did not use to be employed in the Netherlands in relevant time, they were affected by the income criterion much more than men. The group of persons affected by the amendments consisted of about 3,300 women and 1,800 men. ${ }^{10}$ The ECtHR investigated whether the different treatment, based on the income requirement as a criterion, was objectively and reasonably justified in respect of women who were disproportionally affected. It concluded that a purpose of amendments to the General Labour Disablement Benefits Act in 1979 and 1989 - altering the nature of the social insurance scheme from an insurance against loss of income opportunities to an insurance against loss of income - was legitimate in view of the necessity to keep the costs of the social insurance scheme within reasonable budgetary limits and due to that they were not contrary to Article 14 of the ECHR.

\subsection{The Opuz Case}

The applicant and her mother were exposed to domestic violence which resulted in torture of the applicant and death of her mother. The ECtHR found on a basis of statistical evidence, submitted by two reliable NGO's, which were not challenged by the Government, that "the general and discriminatory judicial passivity in Turkey, albeit unintentional, mainly affected women". ${ }^{11}$ The Court considered that the violence suffered by the applicant and her mother was gender-based violence which was a form of discrimination against women and that there was insufficient readiness of Turkish authorities to take appropriate action to suppress domestic violence. ${ }^{12}$ A group suffering domestic violence consisted of children and women, but women were the highest number of victims.

\subsection{The Zarb Adami Case}

In 1997 the number of men on the list of jurors in Malta was three times that of women. In 1996 five women and 174 men served as jurors. ${ }^{13}$ According to Article 603(1) of the Maltese Criminal Code, "Every person of the age of twenty-one years or upwards, residing in Malta and being a citizen of Malta, shall be qualified to serve as a juror provided such person has an adequate knowledge of the Maltese language, is of good character and is competent to serve as a juror." ${ }^{\prime 4}$ According to Article 605 of the Criminal Code the commis-

\footnotetext{
${ }^{10}$ Hoogendijk, op. cit., p. 21.

${ }^{11}$ Opuz, op. cit., paras 193, 198, 200.

12 Ibid., para 200.

${ }^{13}$ Zarb Adami, op. cit., para 77 .

${ }^{14}$ Ibid., para 30.
} 
sioner of police, two magistrates and the registrar of the courts compiled the lists of jurors. The lists are published in the Government Gazette in August each year. ${ }^{15}$ Persons from the list may object to the criminal court against their placement on the list alleging that they do not possess the required qualifications. After a decision of the court, the registrar corrects the list. The names of jurors are written down on separate ballots and every month ballots are drawn. ${ }^{16}$ There is nothing discriminatory in the provisions. Distinctions based on the age, place of residence, citizenship, knowledge of the Maltese language, good character and competence were reasonable and justified. No one of them privileged one sex over the other. An exemption might be found in Article 604(3) of the Criminal Code according to which persons who had to take care of their family could have been exempted from jury service. More women than men could have relied on that provision. ${ }^{17}$ The ECtHR concluded that discrimination "may result not only from a legislative measure (...), but also from a de facto situation". ${ }^{18}$ However, de facto situation - a disproportional participation of men in juries - was created by an application of the said provisions. The disproportional situation has started to change towards balanced representation of two genders. The change was a consequence of certain measures which were taken in the meantime such as adding government or bank employers as well as university graduates to the lists of jurors, among which women were well-represented. ${ }^{19}$ Obviously, something was wrong with the application of the provisions. It can be concluded that the provisions of Maltese Criminal Code related to eligibility of members for juries were really neutral but application of the provisions was discriminatory.

\subsection{The D.H. and Others Case}

The Czech Schools Act from 1984 provided special schools for children with „mental deficiencies”, ordinary primary schools and specialised primary schools for children suffering from sensory impairment, illness or disability. ${ }^{20}$ Classification of schools was changed by the new Schools Act from 2004 according to which there were primary schools and specialised primary schools for children with severe mental disability or multiple disabilities and for autistic children. ${ }^{21}$ According to the relevant Decree from 1997 a range of subjects were empowered to propose an allocation of a pupil in special school, inter alia the

\footnotetext{
${ }^{15}$ Ibid., para 31.

${ }^{16}$ Ibid.

${ }^{17}$ Ibid., para 81.

${ }^{18}$ Zarb Adami, op. cit., para 76 .

${ }^{19}$ Ibid., para 54.

${ }^{20}$ D.H. and Others, op. cit., para 30.

${ }^{21}$ Ibid., para 31.
} 
pupil's legal guardian, the pupil's current school or an educational psychology centre. The head teacher was empowered to decide to allocate a pupil to special school, but consent of the pupil's legal guardians was necessary. An educational psychology centre was obliged to collect all the documents relevant to the decision and to make a recommendation to the head teacher concerning the type of school. $^{22}$ To evaluate intellectual capacity of a child, an educational psychology centre used tests. The testing was neither compulsory nor automatic. Teachers or paediatricians proposed testing either when the child first enrolled at the school or if difficulties were observed in its ordinary primary-school education. ${ }^{23}$ The Czech Government admitted that the psychological tests "are conceived for the majority population and do not take Romani specifics into consideration". ${ }^{24}$ The Advisory Committee on the Framework Convention found in its first report on the Czech Republic that "it appeared that many Roma children who were not mentally handicapped were placed in them owing to real or perceived language and cultural differences between Roma and the majority". ${ }^{25}$ The Czech authorities acknowledged that in 1999 Roma pupils consisted between $80 \%$ and $90 \%$ of the total number of pupils in some special schools and various international bodies observed that a disproportionately large number of Roma children were situated in special schools. ${ }^{26}$ The ECtHR found that the relevant statutory provisions were formulated in neutral terms, but they had significantly more impact in practice on Roma children than on non-Roma children and resulted in statistically disproportionate numbers of Roma children in special schools. ${ }^{27}$ It stated that the Czech authorities failed to take into account special needs of Roma children as members of a disadvantaged class. ${ }^{28}$

\subsection{The Oršuš and Others Case}

Minority of judges of the Grand Chamber in Oršuš and Others stressed "that in a situation like the present one in which the Court is overruling a wellreasoned judgment by a Constitutional Court, as well as a unanimous judgment of one of its Chambers, by adopting a Grand Chamber judgment by a nine to eight vote, it should have presented more convincing arguments to justify its decision. In addition, it would have been useful if the Court had been willing to offer more practical guidance on how to develop and apply the notion of indi-

\footnotetext{
${ }^{22}$ Ibid., para 36.

${ }^{23}$ Ibid., para 39.

${ }^{24}$ Ibid., para 41.

${ }^{25}$ Ibid.

${ }^{26}$ Ibid., para 192.

${ }^{27}$ Ibid., para 193.

${ }^{28}$ Ibid., para 207.
} 
rect discrimination." 29 The disputed issue was whether an allocation of Roma children in separate classes of primary schools due to their inadequate command of Croatian language amounts to indirect discrimination? The minority of judges underlined that organising teaching in mixed classes where a high percentage or even a majority of pupils does not have sufficient knowledge of the language of teaching causes some difficulties. Satisfaction of special additional needs of these pupils requires certain adaptation of lecturing to their needs and that adaptation might be at expenses of progress of pupils without special needs. The minority objected that the majority of judges did not pay due attention to the importance for Croatian-speaking pupils of being able to progress properly at school. ${ }^{30}$ Whether insufficient knowledge of language of teaching does objectively and reasonably justify segregation of Roma children in separate classes? Majority of judges considered that the central question was "whether adequate steps were taken by the school authorities to ensure the applicants' speedy progress in acquiring an adequate command of Croatian and, once this was achieved, their immediate integration in mixed classes“. ${ }^{31}$ Majority noted that nonRoma parents opposed replacement of separate classes by mixed classes in some schools and created an atmosphere of intolerance. ${ }^{32}$ Besides, it noted certain inconsistencies in a justification offered by the Government. Two applicants were placed initially in a mixed class. After two years they were transferred to a Roma-only class. Majority of judges had a problem to understand why the two applicants would have sufficient knowledge of the Croatian language at the age of seven, but no longer two years later. ${ }^{33}$ Small percent of Roma pupils, several times smaller than general population, completed primary school. ${ }^{34}$ A psychological study of Roma children attending Roma-only classes in Croatian county Medimurje asserted that "segregated education produced emotional and psychological harm in Roma children, in terms of lower self-esteem and self-respect and problems in the development of their identity". ${ }^{35}$ After investigating the facts of the case, majority found that "the schooling arrangements for Roma children were not sufficiently attended by safeguards that would ensure that, in the exercise of its margin of appreciation in the education sphere, the State had sufficient regard to their special needs as members of a disadvantaged group“" ${ }^{36}$

${ }^{29}$ Oršuš and Others, op. cit., Joint partly dissenting opinion of judges Jungwiert, Vlajić, Kovler, Gyulumyan, Jaeger, Myjer, Berro-Lefèvre and Vučinić, para 19.

${ }^{30}$ Ibid., para 9.

${ }^{31}$ Oršuš and Others, op. cit., para 145.

${ }^{32}$ Ibid., para 154.

${ }^{33}$ Ibid., para 161.

${ }^{34}$ Ibid., para 18.

${ }^{35}$ Ibid., para 53.

${ }^{36}$ Ibid., para 182. 
The majority concluded that "there were at the relevant time no adequate safeguards in place capable of ensuring that a reasonable relationship of proportionality between the means used and the legitimate aim said to be pursued was achieved and maintained“" ${ }^{37}$ Really, the issue of insufficient knowledge of a language of teaching might have been addressed in other way. In 2002 Croatia introduced two years pre-school programme to prepare all Roma children for schools, which includes learning of Croatian language.

\subsection{The Sampanis et autres Case}

The case is comparable to Oršuš and Others. In Aspropyrgos, a suburb of Athens, Roma pupils were separated in three prefabricated rooms constituting an annex of the Primary school. ${ }^{38}$ They attended preparatory classes there to learn Greek language and to accommodate to school conditions. But, over three years, a period under appeal, they were not moved to regular classes. An evaluation of their progress, which would enable them to join regular classes, was not performed. ${ }^{39}$

\subsection{The Horváth and Kiss Case}

The case is similar with D.H. and Others. Hungary had remedial primary schools for mentally disabled children. Less than $1 \%$ of students with special needs had the opportunity to continue education in mainstream secondary education providing the Baccalaureate. " "The systemic misdiagnosis of Roma children as mentally disabled has been a tool to segregate Roma children from nonRoma children in the Hungarian public school system since at least the 1970s." $" 41$

\section{Cause for the Extension of Article 14 of the ECHR to Indirect Discrimination}

Reasoning of the ECtHR on indirect discrimination was influenced by the analogous concept developed in EU law. In D.H. and Others the ECtHR referred to legal sources of EU rules on indirect discrimination. It quoted relevant provisions of some EU anti-discrimination directives as well as leading judgments of the Court of European Communities.

\footnotetext{
${ }^{37}$ Ibid., para 184.

${ }^{38}$ Sampanis et autres, op. cit., para 82.

${ }^{39}$ Ibid., para 81.

${ }^{40}$ Horváth and Kiss, op. cit., paras 6-8.

${ }^{41}$ Ibid., para 9.
} 
The Court of European Communities initially used the concept to overcome an obstacle caused by exhaustive numbering grounds of discrimination. ${ }^{42}$ Before the Amsterdam Treaty, the Founding Treaties and secondary EC law contained provisions prohibiting discrimination based on nationality in general and on sex in some matters. The Court of European Communities faced the problem when a different treatment was not based on nationality or sex but on other grounds which were also affecting members of the protected groups - foreign nationals or women. To resolve the problem, the Court of European Communities found that these EC non-discrimination provisions prohibited not only overt discrimination, based on forbidden grounds, but also "all covert forms of discrimination which, by applying other distinguishing criteria, lead in fact to the same result". ${ }^{43}$ In Sotgiu the Court of European Communities applied prohibition of discrimination based on nationality, as it was provided by Article 7(1) and (4) of Regulation No. 1612/68. It noted that a place of residence of a worker as a criterion for the grant of a separation allowance, which excluded workers who had their places of residence abroad at the time they were taking up a given post, might constitute discrimination, since its practical effect might be the same as discrimination on the ground of nationality. ${ }^{44}$ The criterion of place of residence is apparently neutral in respect to nationality, but in fact it is not, since much more foreign than domestic workers have their place of residence abroad.

The ECtHR did not face a similar problem. Article 14 of the ECHR provides an open list of grounds of discrimination. It numbers some important grounds of discrimination but in exemplary way. It states: "The enjoyment of the rights... shall be secured without discrimination on any ground such as sex, race, colour... or other status". It means that a place of residence may be the ground of discrimination. The Court has interpreted broadly the phrase - "any ground such ... or other status", not reducing it to personal characteristics. ${ }^{45}$ Really, the ECtHR confirmed a place of residence as the ground of discrimination. ${ }^{46}$ So, the ECtHR would analyse in Sotgiu whether a different treatment based on place of residence was objectively and reasonably justified. Foreign workers would be protected as probably the biggest part of workers who had their place of residence abroad at the moment of taking employment. But, the Court

${ }^{42}$ R. Etinski, I. Krtić, EU Law on the Elimination of Discrimination, Belgrade, Maribor, 2009, p. 150.

${ }^{43}$ Case 152-73, Giovanni Maria Sotgiu v. Deutsche Bundespost, judgment of 12 February 1974, para 11.

${ }^{44}$ Ibid., paras $11,13$.

${ }^{45}$ See critics of certain ambivalence in the practice of the ECtHR in respect of grounds of discrimination: J. Gerards, The Discrimination Grounds of Article 14 of the European Convention on Human Rights, Human Rights Law Review (2013), 1-26.

${ }^{46}$ Vučković and others v. Serbia (App. No. 17153/11), judgment of 28 August 2012, para 87. 
would not investigate whether a different treatment was objectively and reasonable justified in respect of foreign workers only but whether it was justified in respect to all workers who had their place of residence abroad.

A building of the EU anti-discrimination law started in seventies of the last century through directives that were widening a scope of applicability of Article 119 of the Treaty establishing the European Economic Community (equal pay for male and female workers for equal work) and gradually introducing various anti-discrimination tools. Now the EU anti-discrimination law includes four major anti-discrimination directives. ${ }^{47}$ The concept of indirect discrimination was further developed in the framework of the EU anti-discrimination directives. The development was determined by a purpose of the EU anti-discrimination law - achievement of full equality for all members of society in some social fields and due to that aim, focusing a care to particularly vulnerable groups, such as women and various minorities. The Council of Europe has devoted its attention to protection of minorities in last decades. Such political and legal development has created a legal context which stimulated the ECtHR to extend a scope of applicability of Article 14 of the ECHR to indirect discrimination. It is indicative that the ECtHR has repeated several times "that there could be said to be an emerging international consensus amongst the Contracting States of the Council of Europe recognising the special needs of minorities and an obligation to protect their security, identity and lifestyle, not only for the purpose of safeguarding the interests of the minorities themselves but to preserve a cultural diversity of value to the whole community". ${ }^{48}$

\section{Concept of Indirect Discrimination as Developed by the ECtHR}

The concept is based on a well-established meaning of term "discrimination" - "discrimination means treating differently, without an objective and rea-

${ }^{47}$ Council Directive 2000/43/EC of 29 June 2000 implementing the principle of equal treatment between persons irrespective of racial or ethnic origin prohibits discrimination on grounds of racial or ethnic origin as regards employment, social protection, education and access to and supply of goods and services; Council Directive 2000/78/EC of 27 November 2000 establishing a general framework for equal treatment in employment and occupation forbids discrimination on grounds of religion or belief, disability, age or sexual orientation as regards employment and occupation; Council Directive 2004/113/EC of 13 December 2004 implementing the principle of equal treatment between men and women in the access to and supply of goods and services prohibits discrimination based on sex in respect of access to and supply of goods and services; and Directive 2006/54/EC of the European Parliament and of the Council of 5 July 2006 on the implementation of the principle of equal opportunities and equal treatment of men and women in matters of employment and occupation (recast) forbids discrimination based on sex as regards employment and occupation.

${ }_{48}$ Chapman v. the United Kingdom (App. no. 27238/95), Judgment of 18 January 2001, para 93, D.H. and Others, op. cit., para 181, Sampanis et autres, op. cit., para 72. 
sonable justification, persons in relevantly similar situations". ${ }^{49}$ That understanding is supplemented by an important old observation of the ECtHR that Article 14 does not prohibit a Member State to treat groups differently if it serves to correct factual inequalities between them. The Court underlined that in certain circumstances a failure of a State "to attempt to correct inequality through different treatment may in itself give rise to a breach of the Article". ${ }^{50}$ That old observation from $1968^{51}$ has got new importance in a context of indirect discrimination.

The concept of indirect discrimination is expressed in various versions. A version states: "a general policy or measure that has disproportionately prejudicial effects on a particular group may be considered discriminatory notwithstanding that it is not specifically aimed at that group". ${ }^{52}$ Another version reads as follows: "a general policy or measure which is apparently neutral but has disproportionately prejudicial effects on persons or groups of persons who ... are identifiable only on the basis of an ethnic criterion, may be considered discriminatory notwithstanding that it is not specifically aimed at that group" ${ }^{53} \mathrm{Or}$, an indication of indirect discrimination exists when "a specific rule - although formulated in a neutral manner - in fact affects a clearly higher percentage of women than men". ${ }^{54}$

Instead a term "treatment" which is used by the Court for general definition of discrimination, the ECtHR uses terms "general policy", "measure" and "specific rule". A term "treatment" denotes legal treatment, which includes legislation and application of the law. Terms "general policy and measure" indicate something outside the law in strict sense.

Three requirements closely interrelated distinguish the concept of indirect discrimination - apparently neutral policy, measure or rule - disproportionately prejudicial effects - policy, measure or rule not specifically aimed at the group.

What does it mean "apparently neutral"? A criterion of pregnancy is not neutral in respect of sex. Or, a criterion of colour is not neutral in respect of ra-

${ }^{49}$ Fredin v. Sweden (no. 1), (App. no.12033/86) Judgment of 18 February 1991, para 60, Willis v. the United Kingdom, (App. no. 36042/97), Judgment of 11 June 2002, para 48, D.H. and Others, op. cit., para 175, Opuz, op. cit., para 183, Sampanis et autres, op. cit., para 67, Oř̌uš and Others, op. cit., para 149, Horváth and Kiss, op. cit., para 101.

${ }^{50}$ D.H. and Others, op. cit., para 175, Sampanis et autres, op. cit., para 68, Oršuš and Others, op. cit., para 149, Horváth and Kiss, op. cit., para 101

${ }^{51}$ Case relating to certain aspects of the laws on the use of languages in education in Belgium v. Belgium (Merits), Judgment of 23 July 1968, para 10.

${ }^{52}$ Hugh Jordan v. the United Kingdom (App. no. 24746/94) Judgment of 4 May 2001, para 154, D.H. and Others, op. cit., para 175, Opuz, op. cit., para 183.

${ }^{53}$ Sampanis et autres, op. cit., para 68, Oršuš and Others, op. cit., para 150, Horváth and Kiss, op. cit., para 105.

${ }^{54}$ Hoogendijk, op. cit., p. 21, D.H. and Others, op. cit., para 180. 
ce. It means a general characteristic which is shared exclusively by members of a particularly vulnerable group cannot be an apparently neutral criterion. Consequently, an apparently neutral criterion is a general characteristic which is shared by members of various populations, but which characterizes members of a particularly vulnerable group disproportionally more than members of other population. In that sense, disproportionally prejudicial effects mean less favourable effects that affect a group of various populations among whom members of particularly vulnerable group are represented more than others. Intent of a State to affect members of a particularly vulnerable group by neutral policy, measure or rule is not necessary for appearance of indirect discrimination.

The ECtHR has completed the concept of indirect discrimination by referring to its practice concerning burden of proof and evidence. It has repeated its old position "that once the applicant has shown a difference in treatment, it is for the Government to show that it was justified". ${ }^{55}$ In some recent cases, "in which the applicants alleged a difference in the effect of a general measure or de facto situation (...), the Court relied extensively on statistics produced by the parties to establish a difference in treatment between two groups (men and women) in similar situations". ${ }^{56}$ The ECtHR states also that when it assesses the impact of a measure or practice on an individual or group, reliable and significant statistics will be sufficient to constitute the prima facie evidence the applicant is required to produce. ${ }^{57}$ Though, statistical evidence is not an exclusive proof of indirect discrimination. ${ }^{58}$

Since the four cases related to indirect discrimination affecting Roma pupils, children of the same ethnic group, which is a form of racial discrimination, the ECtHR devoted its attention to specificities of racial discrimination. Being a particularly invidious kind of discrimination and producing perilous consequences, racial discrimination "requires from the authorities special vigilance and a vigorous reaction. It is for this reason that the authorities must use all available means to combat racism, thereby reinforcing democracy's vision of a society in which diversity is not perceived as a threat but as a source of enrichment". ${ }^{2}$ Starting from that, the ECtHR stated that different treatment based exclusively or to a decisive extent on a person's ethnic origin cannot be objectively justified

${ }^{55}$ D.H. and Others, op. cit., para 177, Opuz, op. cit., para 183, Sampanis et autres, op. cit., para 70 .

${ }^{56}$ D.H. and Others, op. cit., para 180.

${ }^{57}$ D.H. and Others, op. cit., para 188, Horváth and Kiss, op. cit., para 107.

${ }_{58}^{58}$ D.H. and Others, op. cit., para 188, Oršuš and Others, op. cit., para 153.

${ }^{59}$ D.H. and Others, op. cit., para 176, Sampanis et autres, op. cit., para 69, Horváth and Kiss, op. cit., para 101. 
in "contemporary democratic society built on the principles of pluralism and respect for different cultures" ${ }^{60}$ However, in Oršuš the Court has mitigated that position saying: "very weighty reasons would have to be put forward before the Court could regard a difference of treatment based exclusively on the ground of ethnic origin as compatible with the Convention. ${ }^{\prime 61}$ The ECtHR stresses that the vulnerable position of Roma/Gypsies requires "that special consideration should be given to their needs and their different lifestyle both in the relevant regulatory framework and in reaching decisions in particular cases". ${ }^{62}$

\section{Critical Observations}

The four cases of racial discrimination are similar by their substance but different by legal features. The issue is whether a key principle of indirect discrimination, as defined by the ECtHR - "a general policy or measure which is apparently neutral but has disproportionately prejudicial effects on persons or groups of persons..." is applicable to the cases Sampanis et autres and Or ̌̌u $\breve{s}$ and Others? The ground of different treatment in these cases was a language insufficient knowledge of a language of teaching. Whether a language is criterion neutral in respect of ethnic origin? In Sefic the Committee on the Elimination of Racial Discrimination accepted that a different treatment based on language might be a case of racial discrimination. ${ }^{63}$ A language is natural characteristic of an ethnic group but it is not an exclusive characteristic of members of the ethnic group. However, the language criterion did not disproportionately affect Roma children. It affected exclusively Roma children. There were no children of other ethnic origin segregated in separate classes. It implies a question that, assuming that language criterion may be neutral in respect of ethnic origin, whether the second requirement of the principle - disproportional effects - was satisfied? Whether the requirement of disproportional effects consumes effects that affect exclusively members of a vulnerable group? It is worthy to note here that definition of indirect discrimination in the EU anti-discrimination directives does not express the requirement of disproportional effects. ${ }^{64}$

${ }^{60}$ D.H. and Others, op. cit., para 176, Sampanis et autres, op. cit., para 69, Horváth and Kiss, op. cit., para 101.

${ }_{61}^{6}$ Oršsuš and Others, op. cit., para 149.

${ }^{62}$ D.H. and Others, op. cit., para 181, Sampanis et autres, op. cit., para 72.

${ }^{63}$ Emir Sefić v. Denmark (Communication no. 32/2003) Opinion, 7 March 2005.

${ }^{64}$ Article 2 (2b) of Council Directive 2000/43/EC of 29 June 2000 implementing the principle of equal treatment between persons irrespective of racial or ethnic origin states: "indirect discrimination shall be taken to occur where an apparently neutral provision, criterion or practice would put persons of a racial or ethnic origin at a particular disadvantage compared with other persons, unless that provision, criterion or practice is objectively justified by a legitimate aim and the means of achieving that aim are appropriate and necessary". 
The concept of indirect discrimination under Article 14 of the ECHR implies the issue whether the concept is applicable to groups which are not distinguished as particularly vulnerable groups, such as women or minorities groups. Whether the concept is applicable to men, for example? In Zarb Adami the ECtHR found discrimination against men. The case has features of indirect discrimination - a neutral provision whose application produced disproportional effects to men. But, the Court did not label the case as a case of indirect discrimination. The ECtHR noted that discrimination "may result not only from a legislative measure (...), but also from a de facto situation". Whether it means that the Court has reserved the concept of indirect discrimination exclusively for protection of members of particular vulnerable groups? I believe that further practice of the Court will offer a reply. It seems that the Human Rights Committee has opted for indirect discrimination that will protect persons outside particularly vulnerable groups. ${ }^{65}$

\section{Concluding Remarks}

The ECtHR extended the applicability of Article 14 of the ECHR to indirect discrimination in recent years. "An emerging international consensus amongst the Contracting States of the Council of Europe recognising the special needs of minorities and an obligation to protect their security, identity and lifestyle, not only for the purpose of safeguarding the interests of the minorities themselves but to preserve a cultural diversity of value to the whole community" has become a political and legal context that required the extension. The Court defined indirect discrimination as a general policy, measure or specific rule which is apparently neutral but has disproportionately prejudicial effects on members of particularly vulnerable groups and which may be considered discriminatory notwithstanding that it is not specifically aimed at that group. The ECtHR applies the concept of indirect discrimination in a very flexible way. The Court found indirect racial discrimination in cases where discrimination was based on a language and where Roma pupils were affected exclusively. These cases require further clarification of requirement on apparent neutrality of a crite-

${ }^{65}$ In Althammer the Human Rights Committee states: "The Committee recalls that a violation of article 26 (of the International Covenant on Civil and Political Rights - R.E.) can also result from the discriminatory effect of a rule or measure that is neutral at face value or without intent to discriminate. However, such indirect discrimination can only be said to be based on the grounds enumerated in Article 26 of the Covenant if the detrimental effects of a rule or decision exclusively or disproportionally affect persons having a particular race, colour, sex, language, religion, political or other opinion, national or social origin, property, birth or other status. Furthermore, rules or decisions with such an impact do not amount to discrimination if they are based on objective and reasonable grounds." Rupert Althammer et al. v. Austria, Comm. No. 998/2001, views adopted on 8 August 2003, para 10.2. 
rion of different treatment as well as requirement of disproportional effects. Further practice of the Court will clarify also whether the concept of indirect discrimination will be used for protection of members of particularly vulnerable groups only or also for the protection of other groups.

Economic crises is affecting Europe in longer period and contributes to further marginalisation of already marginalized groups and to strengthening of various social prejudices against members of vulnerable groups. Having accepted the concept of indirect discrimination, the ECtHR has broadened a legal field for the fight against such processes. 
Др Родољуб Ейински, редовни ӥрофесор

Универзииетеи у Новом Саду

Правни акулиеей у Новом Саду

\section{Индиректна дискриминација у судској пракси Европског суда за људска права}

Сажжейак: Евройски суд за људска йрава ирроширио је обласии иримене члана 14 Евройске конвенције о људским иравима на индирекйну дискриминаиију у йоследњим іодинама. Суд Евройских заједнииа йочео је да користии овај концейй у седамдесейим іодинама йрошлоі века како би йревазишао оіраничења која су йроистичала из тиаксайивно наведених основа дискриминаиије у ирравилима о забрани дискриминачије у ираву Евройских заједница. Оснивачки уіоовори и секундарно йраво Евройских заједница забрањивали су у дужем иеериоду, све до Амстиердамскоі уі̄овора, дискрими-

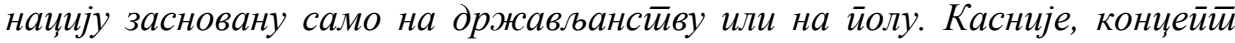
индирекиине дисмриминачије развијан је даље у анииидискриминационом ираву Евройске уније, дакле у анииидискриминационим дирекииивама које су имало за ичиь да обезбеде ирримену начела једнакостии у йојединим обла-

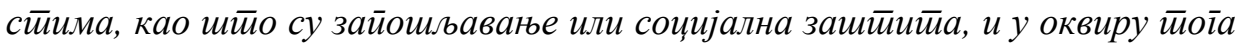
да обезбеде зашимит̄у йосебно рањивих друшимвених іруйа, као шито су же-

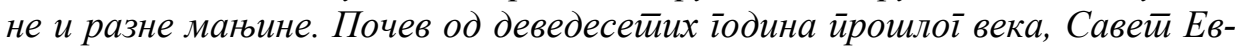
ройе анїажује се на зашититии ииих йосебно рањивих іруйа. Тако је сииворен ирравно-йолитиччки кониекксй у ирвој деценији XXI века који је условио да Евройски суд за људска иррава ирроиетіне ойшйу забрану дискриминаиије из члана 14 Евройске конвенције о људским иравима на индирекйну дискриминацију.

Под индирекӣном дискриминаиијом Евройски суд за људска йрава разуме мање йовољан йрейман који се заснива на неком основу који је неуирралан у односу на йосебно рањиве іруиее, али који йоі̆ђа чланове неке од

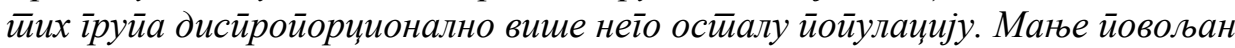
йрейман није заснована, дакле на йолу или на ейничком йореклу, али уйркос йоме он йоі̆ађ више жене неїо мушкарие или йрийадике мањине неїо 


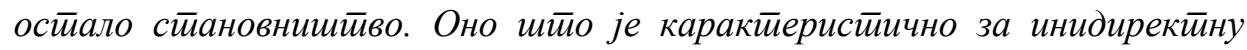
дискриминачију јестеие да се она не чини искључиво ирравним тиреимманом, дакле доношењем закона или друіих оититих йравних акайа и иррименом

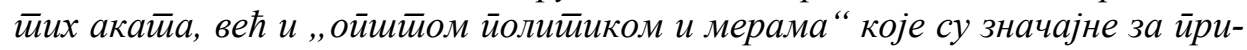
мену иррава. Под неуиралним основом дискриминације разуме се нека ои-

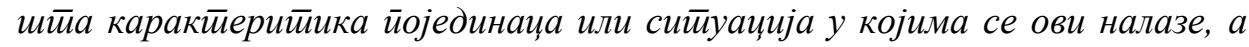
коју не деле искључиво иррийадици неке йосебно рањиве іруйе. Тако, на иример, иирудноћа не може да буде неуирралан основ у односу на йол. Тај неуитрални основ нейовољнијеі ииретимана йоїађа више йрийаднике неке йо-

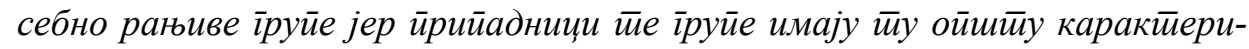
сииику ирройориионално више неїо остиало стиановнишимво.

Евройски суд за људска йрава йрименио је концейй индирекиине дискриминације у неким случајевима у којима је основ нейовољнијеі йреймана било недовољно знање језика на коме се одвијала настиава у основној школи и їде су ромска деца била искључиво йоіођена нейовољнијим иирей-

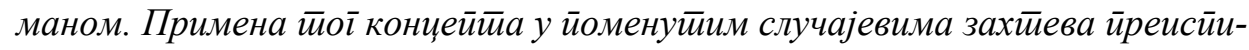
ииивање дефиниције индирекиине дискриминаиије, како ју је одредио Евройски суд за људска иррава.

Кључне речи: индирекӣа дискриминаџија - људска йрава. 